\title{
Az akadémiai-ipari együittmúködések szerepe a gyógyszerfejlesztésben pandémia idején
}

\author{
Keserű György Miklós \\ Gyógyszerkémiai Kutatócsoport, Természettudományi Kutatóközpont, Budapest, Magyarország \\ Magyar Koronavírus-kutatási Akciócsoport \\ Beérkezett: 2021. május 5.; Elfogadva: 2021. július 1.
}

\begin{abstract}
Összefoglalás
Egészen az ezredfordulóig a gyógyszeripari kutatás-fejlesztés világszerte hagyományosan nagyvállalati keretek között folyt. Az elmúlt évtizedekben azonban ebben a szegmensben jelentős átrendeződések tapasztalhatók, ugyanis a korai kutatási és fejlesztési projektek sok esetben már az egyetemi-akadémiai, illetve kkv-szektorból indulnak. A szervezeti keretek mellett a fejlesztések szakmai tartalma is változott, a hagyományos kismolekulás gyógyszerek mellett egyre meghatározóbb szerep jut a biológiai terápiáknak, valamint a hatóanyagok fejlesztése mára összekapcsolódott a releváns diagnosztikumok fejlesztésével. A projektek finanszírozásában is fontos változások történtek, egyre jelentősebb szerep jut az állami KFI finanszírozásnak és a (kockázati) tókebefektetéseknek. A gyógyszeripari K+F szakmai, szervezeti és finanszírozási kereteinek változása jelentősen felértékelte és szélesítette a korábban is meglévő akadémiaiipari kapcsolatokat. Az együttmúködések fontos szerepet játszanak a COVID-19 járványra adott válaszokban is, amit a magyar egyetemek, kutatóintézetek, kis- és középvállalatok, valamint gyógyszeripari nagyvállalatok részvételével indult kutatások igazolnak.
\end{abstract}

Kulcsszavak: egyetem, kutatóintézet, gyógyszeripar, együttmúködés, COVID-19

\section{Drug development collaborations between Academia and Industry in Pandemia}

\author{
György M. Keserű
}

Medicinal Chemistry Research Group, Research Centre for Natural Sciences, Budapest, Hungary

Hungarian Coronavirus Research Task Force

\begin{abstract}
Summary
Until the turn of the millennium, pharmaceutical research and development worldwide had traditionally taken place in pharmaceutical companies. In recent decades, however, significant rearrangements have been witnessed, as earlystage research and development projects often start at the universities or the academic and SME sectors. In addition to the organizational framework, the professional content has also changed: in addition to traditional small molecule drugs, biological therapies are playing an increasingly important role, and the development of active ingredients is now linked to the development of relevant diagnostics. Important changes have also taken place in the financing of projects, with public RDI financing and (venture) capital investments playing an increasing role. Changes in the professional, organizational and funding frameworks for pharmaceutical R\&D have significantly enhanced and broadened existing academic-industrial relations. Collaborations also play an important role in the responses to the COVID-19 epidemic, as evidenced by research involving Hungarian universities, research institutes, small and medium-sized enterprises, and large pharmaceutical companies. The first example is a collaboration of an academic research group and a spin-off company formed from this environment. Researchers of the Eötvös University (ELTE) and others working at the Research Centre for Natural Sciences (RCNS) applied phage display technology to discover new protease inhibitors. They established EvolVeritas Ltd, a spin-off company developing high affinity and high specificity inhibitors of the TMPRSS2 protease that is involved in the SARS-CoV-2 viral entry to host cells. In a parallel research program, the same consortium is working on new inhibitors of the MASP2 protease contributing to the coronavirus mediated activation of innate immunity, particularly the complement system. This latter approach
\end{abstract}


would result in the effective control of microthrombosis events associated with serious COVID-19 infections. Both of the approaches are in the early preclinical phase and further investment would be needed to push these projects into clinical testing. The second example is a collaboration between an academic research group and an SME to reposition of azelastine, an approved antihistamine drug that was found to be effective in blocking SARS-CoV-2 mediated pathogenesis. After successful preclinical studies, the partners have now initiated clinical trials to demonstrate the efficacy of azelastine nasal drops in the prevention and treatment of COVID-19 infections. The third example is a collaboration of academic research groups, a SME and a pharmaceutical company. This consortium develops an antibody-like fusion protein therapeutics that can neutralize the SARS-CoV-2 virus. One component of the ACE2-Fc fusion protein is the relevant portion of angiotensin-converting enzyme 2 (ACE2) produced by recombinant technologies, which binds to the spike protein of the pathogen. The virus thus binds to the fusion protein instead of the ACE2 receptors in human cells. Another component is responsible for the long half-life of IgG, the so-called Fc region. The consortium confirmed that the ACE2-Fc fusion protein inhibits SARS-CoV-2 infection in cell culture, and prevents disease in experimental animals. Preclinical development and the preparation of the core documentation is ongoing, which will soon be submitted to the European Medicines Agency (EMA) to initiate clinical trials. The final example is a joint development project that involved a research group, an SME and two pharmaceutical companies. The objective of this program is process development and pharmaceutical formulation of favipiravir, a broad-spectrum antiviral with a treatment potential against COVID-19. The consortium completed the process development of the active pharmaceutical ingredient (API) and developed finished dosage formulations available for clinical testing. Clinical trials are ongoing that aim investigating safety and efficacy of favipiravir in COVID-19 infected patients. All of the examples described here demonstrate the power of collaborations that helped the participants to give diverse and effective responses to the unprecedented pandemic challenge of COVID-19. We believe that these experiences would encourage the members of the academic and industry community to formulate further collaborations to tackle the unmet medical need in our societies.

Keywords: university, academia, pharmaceutical companies, collaboration, COVID-19

A kétezres évek első évtizedére a gyógyszeripari elemzók között szinte általánossá vált az a meggyőződés, amely szerint az adott évben bevezetett új gyógyszerek 1996 és 2003 között folyamatosan csökkenó, majd 2004 és 2010 között stagnáló számának hátterében az iparági kutatásfejlesztés hatékonyságának problémái állnak (Mullard 2018). A nemzetközi gyógyszeripar erre a felismerésre a kutatás-fejlesztéssel foglalkozó egységek számának csökkentésével, jelentős kutatói elbocsátásokkal és további vállalati összevonásokkal reagált, amelyek együttesen végül számottevő mértékben csökkentették a gyógyszeriparban foglalkoztatott $\mathrm{K}+\mathrm{F}$ létszámot. Ráadásul a gyógyszeripari szereplók egyes kiemelten erőforrásigényes és a klinikai vizsgálatok kimenetele szempontjából nagyobb kockázatokat jelentő terápiás területról is kivonultak. Bár a gyógyszeripari $\mathrm{K}+\mathrm{F}$ hatékonyságának növelését ezek az intézkedések önmagukban nem voltak képesek lényegesen elősegíteni, azonban hozzájárultak az iparág $\mathrm{K}+\mathrm{F}$ trendjeinek az elmúlt évtizedekben tapasztalt változásához. A továbbra is kielégítetlen orvosi igényekkel egyidejúleg jelentkező $\mathrm{K}+\mathrm{F}$ erőforráshiány és finanszírozás a korábban alapvetően vállalatokra alapozott kutatási és fejlesztési tevékenységben átrendeződéseket eredményezett. Egyfelől a korai kutatási és fejlesztési projektek ma már sok esetben az egyetemi-akadémiai, illetve a kkv-szektorból indulnak. Ebben a fejlesztések szakmai tartalmának változásai is szerepet játszanak: hagyományos kismolekulás gyógyszerek mellett egyre meghatározóbb szerep jut a biológiai terápiáknak, valamint a hatóanyagok fejlesztése mára összekapcsolódott a releváns diagnosztikumok fejlesztésével. Másfelől a fejlesztési projektek korai szakaszának finanszírozásában egyre jelentősebb szerep jut az állami KFI finanszírozásnak és a (kockázati) tókebefektetéseknek.

Ezek a változások együttesen arra késztették a gyógyszeripari szereplőket, hogy a korábban is létezô akadémiai-ipari kapcsolatok intenzifikálására új együttmúködési formákat és versenyképesebb feltételrendszert dolgozzanak ki. Ezek között érdemes megemlíteni a nyílt innovációs modellt, különböző PPP konstrukciókat, új versenypályázati lehetőségeket, valamint oktatási és továbbképzési együttmúködéseket (Khanna 2012). A vállalati $K+F$ létszám csökkentésével a kikerülő munkavállalók jelentős része éppen az egyetemi-akadémiai szférában, illetve a kkv-szektorban helyezkedett el. Ezek a szektorok így mára már nem csupán az ötletgenerálásban kaphatnak szerepet, hanem a képzett munkaerőnek és a megfelelő finanszírozásnak köszönhetően valódi partnerként tudnak együttmúködni a gyógyszeripari szereplőkkel.

Az akadémiai-ipari együttmúködések a gyógyszerkutatások történetében jelentős mértékben járultak hozzá új terápiás lehetőségek azonosításához. Az 1998 és 2007 között az Egyesült Államokban elfogadott 252 kismolekulás és biológiai gyógyszerból $58 \%$-ot a gyógyszeripar önállóan, 24\%-ot az egyetemi-akadémiai szektorral közösen fejlesztett, míg a többi gyógyszer a kkv-szektorhoz volt köthető (Kneller 2010). Egy másik elemzés 357, az amerikai hatóság (FDA) által jóváhagyott gyógyszert vizsgálva azt találta, hogy ezek $48 \%$-a köthető az akadémiai szektorhoz (Lincker-Ziogas-Carr 2014). Egy szélesebb körú vizsgálat immár 1453 FDA által elfogadott eredeti gyógyszer 55\%-a esetében igazolta a közszféra részvételét (Patridge et al. 2015). Az egyetemi 


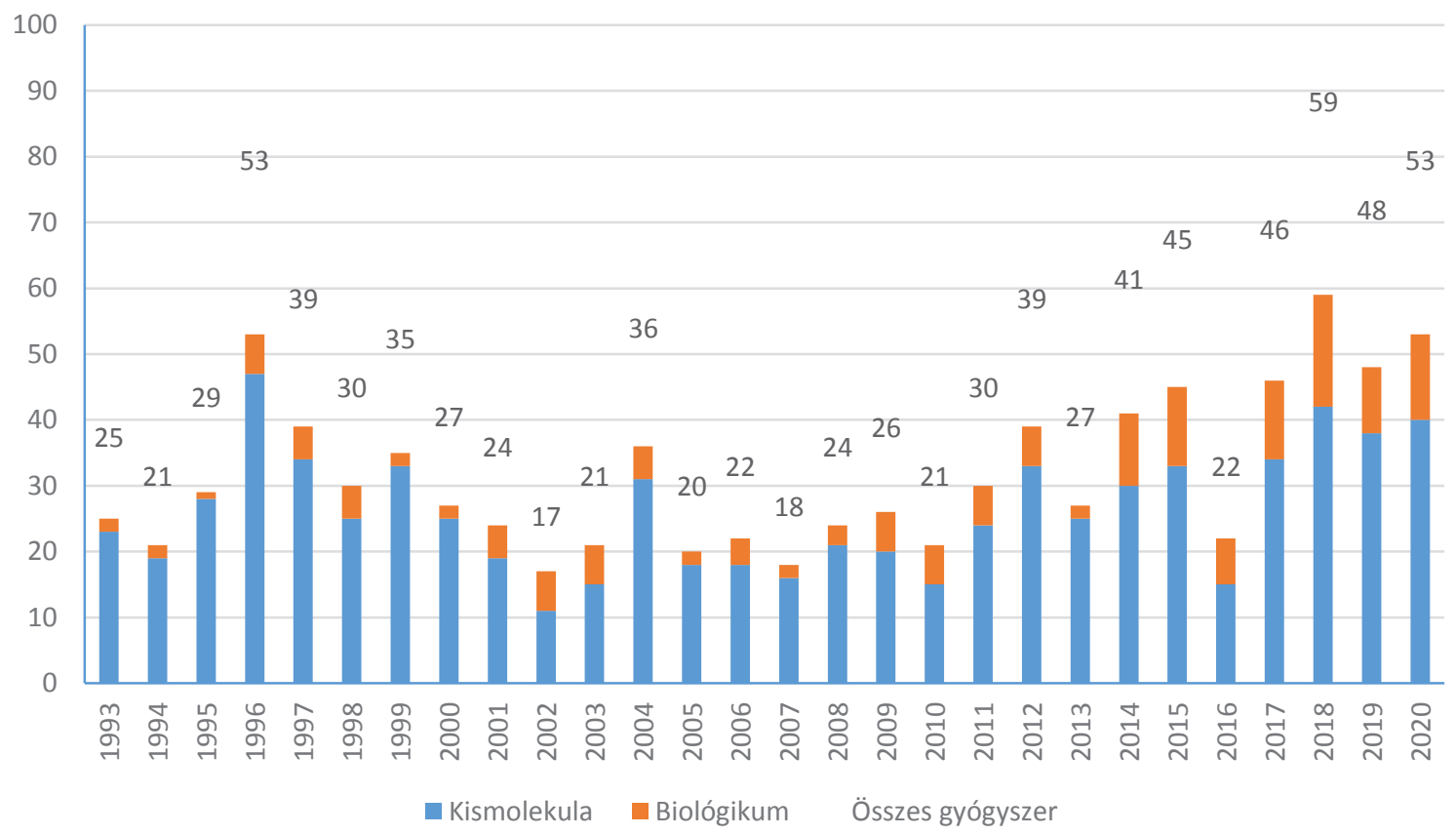

1. ábra

| Az amerikai FDA által engedélyezett gyógyszerek számának alakulása 1993 és 2020 között (forrás: FDA)

akadémiai szektor azonban nemcsak a gyógyszerek, de az új terápiás megközelítések esetében is meghatározó szerepet játszott. Gondoljunk csak a humaniziált antitestekre, a fágbemutatásra, a CTLA-4 és PD-1 vagy a CAR-T immunterápiákra, vagy akár az RNS-alapú terápiás lehetőségekre, amelyek kivétel nélkül az akadémiai szférából indultak.

Nem csoda tehát, hogy a gyógyszerkutatás és fejlesztés szakmai, szervezeti és finanszírozási hátterének jelentős változásával az akadémiai együttmúködések felértékelődtek (Schubmacher-Gassmann-Hinder 2016). Amellett, hogy az együttmúködések egy-egy projektre fókuszálnak, megjelentek a módszertani fejlesztésekre irányuló törekvések, amelyek új, a gyógyszerkutatás számára értékes kémiai, biológiai, orvostudományi eszközöket adnak a vállalati szakemberek kezébe. Az együttmúködések kiterjednek a gyógyszercélpontok azonosítására, validálására és kiindulópontok azonosítására is. Számos esetben jönnek létre akár több egyetemi akadémiai szereplőt és kkv-t magukba foglaló konzorciumok, amelyek megfelelő finanszírozást és a szellemi tulajdon területén a hozzájárulással arányos jogokat kínálnak a résztvevőknek. Az FDA által engedélyezett gyógyszerek éves számának 2010-től megfigyelhető növekedésében a biológiai terápiák növekvő száma mellett valószínúsíthetően a számosságában és tartalmában is kiterjedtebb akadémiaiipari együttmúködések is szerepet játszanak (1. ábra).

Az együttmúködés lehetősége, sôt mondhatjuk azt, hogy kényszere különösen kritikussá válik az olyan rendkívüli helyzetekben, amelyet a SARS-CoV-2-vírus okozta világméretű COVID-19 pandémia eredményezett. A 2020 elejére világméretű járvánnyá vált COVID-19 fertőzés egészségügyi, gazdasági és társadalmi szempontból egyaránt új helyzet elé állította még a legfejlet- tebb országokat is. A tudomány és a kutatók együttmúködése meghatározó szerepet játszott a COVID-19 betegség szakaszainak, az ezeket jellemző alapvetó patofiziológiás folyamatoknak, valamint magának a kórokozónak a megismerésében. A SARS-CoV-2-vírus genetikai kódjának 2020. januári megismerését követően (https://virological.org/t/novel-2019-coronavirus-genome/319) vált nyilvánvalóvá, hogy a kórokozó az RNS vírusok közé, ezen belül pedig a koronavírusok családjába tartozik. A kutatások feltárták a vírus szaporodásának mechanizmusát, sőt 2020 áprilisára ismertté vált az ebben szerepet játszó fehérjék szerkezete és funkciója is. Ezzel sikerült azonosítani a vírusfertőzés molekuláris patomechanizmusában a lehetséges beavatkozási pontokat. A gyógyszercélpontként azonosított vírusfehérjéket gátló molekulákhoz alapvetően két stratégiával juthatunk. A gyógyszerkutatás és fejlesztés klasszikus útját követve előbb kémiai kiindulópontot keresünk, majd ennek sokszempontú optimálásával gyógyszerjelöltet találunk, aminek hatékonyságát és biztonságosságát klinikai vizsgálatokban igazoljuk. A mielőbbi kezelési lehetőségek azonosítása érdekében azonban érdemes egy másik koncepciót is megpróbálni, amikor a vírusfehérjék múködését és a vírus szaporodását más betegségek kezelésére szolgáló, már ismert gyógyszerekkel próbáljuk meg gátolni (Guy et al. 2020). A következőkben hazai példák segítségével kívánom bemutatni azokat az akadémiaiipari együttmúködéseket, amelyek szerepet játszanak, vagy akár a jövőben hozzájárulhatnak a COVID-19 fertőzöttek hatékonyabb kezeléséhez. Fontos megjegyezni, hogy a hatékony védőoltások nélkülözhetetlenek a járvány kezelésében. Ugyanakkor több tényező is arra enged következtetni, hogy a társadalmi immunitás elérése a vártnál később, akár jelentősen elhúzódva valósul csak 
meg. A lakosság oltási hajlandósága, az oltottak immunvédelmének szintje, az immunkomprimált betegek immunvédelme, a vakcináció logisztikai problémái, valamint a gyorsabban terjedő vírusvariánsok jelentősen befolyásolják a vakcináció hatékonyságát. Ráadásul a koronavírusok ellen általában viszonylag rövid életű védettség alakul ki, így fel kell készülnünk arra, hogy huzamosabb időn keresztül kényszerülünk együtt élni a SARS-CoV-2 koronavírussal. A jelenlegi járvány és a vírus tovább élése pedig szükségessé teszi, hogy a betegek kezelésére hatékony terápiás eszközök álljanak rendelkezésre.

\section{Akadémiai felfedezés - spin-off fejlesztés}

A SARS CoV-2-vírus fertőzésének egyik kulcslépése a vírusburok és a sejtmembrán fúziója. Ebben a folyamatban három fehérje vesz részt: (1) a vírus tüskefehérjéje (S-fehérje), ami receptorként használja a humán sejtek felszínén lévő (2) ACE2 fehérjét, és egy szintén sejtfelszíni fehérje, (3) a transzmembrán szerin proteáz 2 (TMPRSS2), amely az S-fehérjét elhasítva beindítja a membránfúziós folyamatot (2. ábra).
A vírusfertőzés gátlására vírusfehérjék és humán fehérjék is szolgálhatnak gyógyszercélpontként. A TMPRSS2, mint humán fehérje, azért is ígéretes gyógyszercélpont, mert stabilnak tekinthető, ellentétben a vírusfehérjékkel, amelyek a vírusgenom magas mutációs rátája miatt gyorsan változhatnak (Hoffmann et al. 2020). A vírusfehérjék gátlására kifejlesztett inhibitorok ellen idővel rezisztencia alakulhat ki.

Az ELTE és az ELKH kutatói által alapított spin-off cég, az EvolVeritas Kft. által elindított projektek egyik célja, nagy specifitású és hatékonyságú inhibitorok fejlesztése a TMPRSS2 proteáz ellen. Az inhibitorfejlesztés az EvolVeritas Kft.-ben már korábban is nagy sikerrel alkalmazott in vitro fehérjeevolúciós technikán, a fágbemutatáson alapul. A módszerrel egy, az emberi szervezetben jelen lévő inhibitorvázból kiindulva milliárdnyi egyedi variánst készítenek, és kiszelektálják azokat, amelyek specifikusan gátolják a TMPRSS2 proteáz enzimatikus aktivitását. Ehhez először nagy mennyiségben, aktív formában kell előállítaniuk a rekombináns TMPRSS2 proteázt. Ez nem triviális feladat, mivel a TMPRSS2 egy membránfehérje, amely rendkívül hajlamos önmagával és más fehérjékkel diszulfidhidas komplexeket képezni.

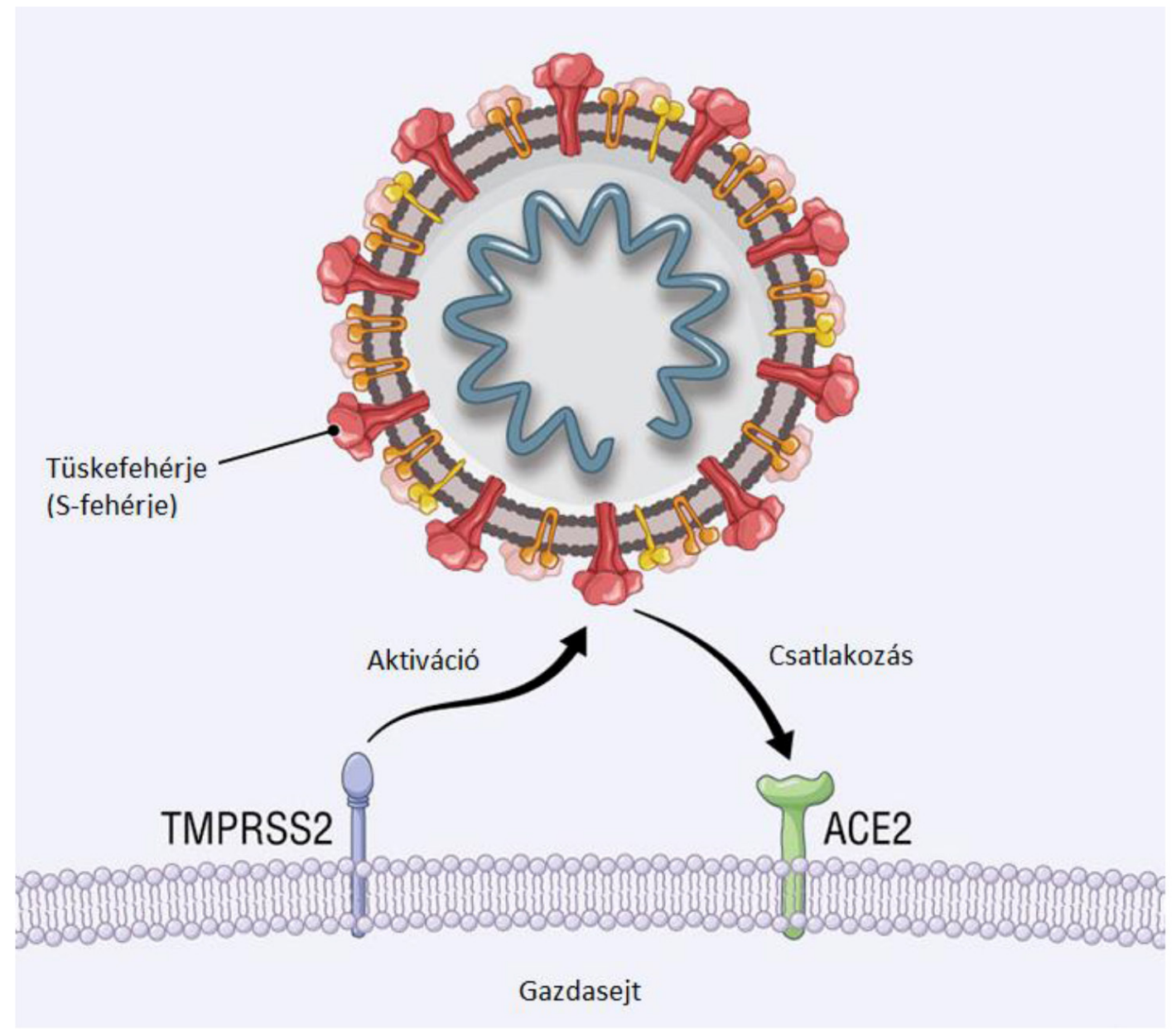


Jelenleg a rekombináns fehérje termelésének és izolálásának optimalizálásán dolgoznak, annak érdekében, hogy megfelelő mennyiségü és minőségü célfehérje álljon rendelkezésre az inhibitorok irányított evolúciójához.

$\mathrm{Az}$ EvolVeritas Kft. olyan hatóanyagokat is fejleszt, amelyek a koronavírus-fertőzés súlyos, gyakran halálos szövődményét, a tüdőgyulladás során a tüdő kis ereiben beinduló véralvadást képesek megakadályozni. Klinikai vizsgálatok kimutatták, hogy a koronavírus túlaktiválja a veleszületett immunitás molekuláris komponensét, a komplementrendszert. A túlzott immunreakció miatt a tüdőben lévő hajszálerekben gyulladásos folyamat, és ennek következtében véralvadás indul el. Az alvadék eltömi az ereket (trombotikus mikroangiopátia), aminek következtében a tüdő nem tudja ellátni funkcióját. A legfrissebb kutatási eredmények szerint a COVID-betegek tüdejében nagy mennyiségben rakódik le a MASP-2 proteáz, ami a komplementrendszer lektin útján az aktiválódás kulcsenzime. Kísérletek bizonyítják, hogy a MASP-2 gátlása kedvezően befolyásolja a betegség lefolyását, csökkenti a gyulladás mértékét. Az EvolVeritas Kft. már rendelkezik szabadalmaztatott MASP-2 inhibitorokkal. Ezek az inhibitorok szintén fágbemutatással készülttek. Jelenleg az inhibitorok újabb generációit állítják elő, amelyek a MASP-2-t még nagyobb specificitással és hatékonysággal gátolják. A legígéretesebb inhibitorok hatását a közeljövőben állatkísérletekben tesztelik.

\section{Akadémiai felfedezés - kkv-fejlesztés}

A Pécsi Tudományegyetem (PTE) Szentágothai János Kutatóközpont (SzKK) és a Nemzeti Virológiai Laboratórium munkatársai az osztrák CEBINA biotechnológiai céggel közösen folytatott vizsgálat eredményeként találtak rá egy már ismert lehetséges hatóanyagra, az azelasztinra, amely új terápiát hozhat a koronavírus-fertőzés kezelésében.

A kutatók egy számítógépes elemzés segítségével kerestek lehetséges patomechanizmust a koronavírus szaporodásának gátlására úgy, hogy elemezték a vírus ellen már hatásosnak bizonyult vegyületek hatásmechanizmusát. A hasonló mechanizmussal múködő már ismert gyógyszereket in vitro körülmények között SARS-CoV-2 fertőzött Vero E6 sejteken és emberi orrszöveten vizsgálták (3. ábra).

A vizsgált gyógyszerek közül az azelasztin jelentős mértékben csökkentette a fertőzést mind prevencióban, mind intervencióban. A kereskedelmi forgalomban is kapható azelasztin tartalmú orrcsepp pedig emberi orrszöveten is csökkentette a vírus szaporodását (https:// www.biorxiv.org/content/10.1101/2020.09.15.2962 28vl.full.pdf). A tapasztalt kedvező hatások így felvetik az azelastin orrcsepp alkalmazásának lehetőségét a koronavírus fertőzés megelőzésében és kezelésében. A hatékonyság igazolására az URSAPHARM Arzneimittel és a CEBINA egy közös klinikai vizsgálatot indított, amelynek célja az azelasztin potenciális SARS-CoV-2-fertőzés

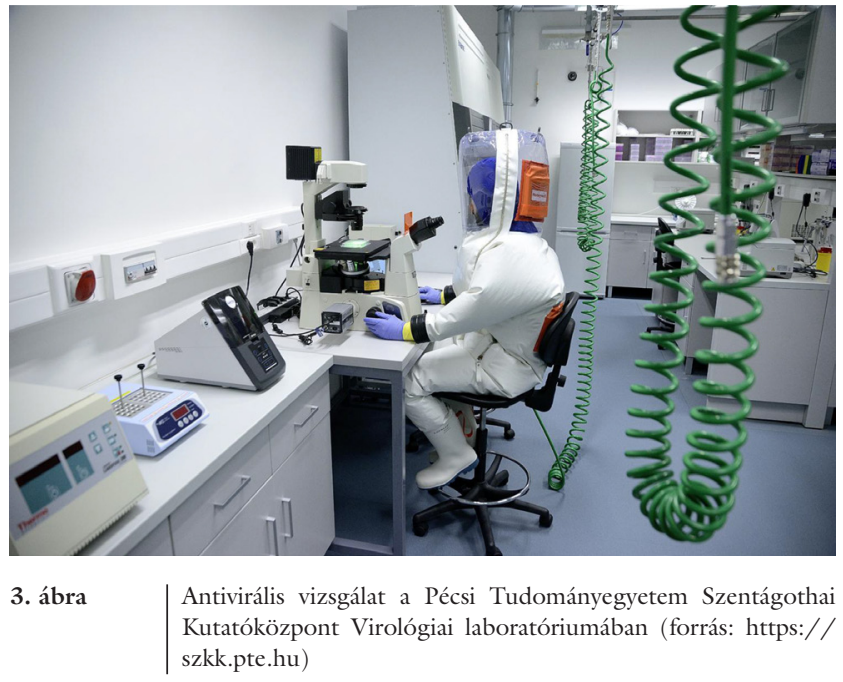

elleni hatásának igazolása a betegek szervezetében. A 2021 februárjában Németországban indult klinikai vizsgálat fó kérdése, hogy az azelasztint tartalmazó orrspray képes-e visszaszorítani az orrnyálkahártyán a vírus megtapadását és szaporodását a fertőzés korai szakaszában, ezáltal megakadályozva a COVID-19 betegség kialakulását, vagy pozitívan befolyásolva a betegség lefolyását és súlyosságát. A külföldi klinikai vizsgálatokkal párhuzamosan az SzKK és a CEBINA szakemberei a magyar klinikai vizsgálat tervezését is megkezdték.

\section{Akadémiai felfedezés - gyógyszeripari fejlesztés}

2020. március közepén négy hazai intézmény kutatóiból és gyógyszerfejlesztőiből álló konzorcium alakult (az NKFIH támogatásával létrejött projektet az Eötvös Loránd Tudományegyetem vezeti, és tagjai a Pécsi Tudományegyetem, a Richter Gedeon Nyrt., valamint az ImmunoGenes Kft.), amely a koronavírus-fertőzést megfékező biológiai hatóanyag kifejlesztésére vállalkozott. A COVID-19 védőoltások eredményeként a vérben is jól detektálható, a vírus tüskefehérjéhez kötődő és a vírust semlegesíteni képes antitestek termelődnek. A védőoltások fejlesztésével egy időben azonnal megkezdődtek azoknak a monoklonális ellenanyagoknak (mEa) a fejlesztései, amelyek a SARS-CoV-2 tüskefehérjét (S-fehérje) specifikusan és nagy affinitással kötik meg és így a vírus fertőzőképességét gátolják. Legtöbbször IgG-típusú mEa-okat fejlesztenek, mert ezek akár 3-5 hónapig is aktívak a szervezetben. A hazai konzorciális fejlesztés során egy mEa hatásához hasonló, a SARSCoV-2-vírus semlegesítésére alkalmas biológiai terápiát (Lei et al. 2020) kívánnak kifejleszteni. A két részből álló fúziós fehérje gyógyszer egyik eleme a vírust a sejtekbe vezető receptor, az angiotenzin-konvertáló enzim 2 (ACE2) szintetikusan előállított része, amely a kórokozónak ahhoz a részéhez (az S-fehérjéjéhez) kapcsolódik, 


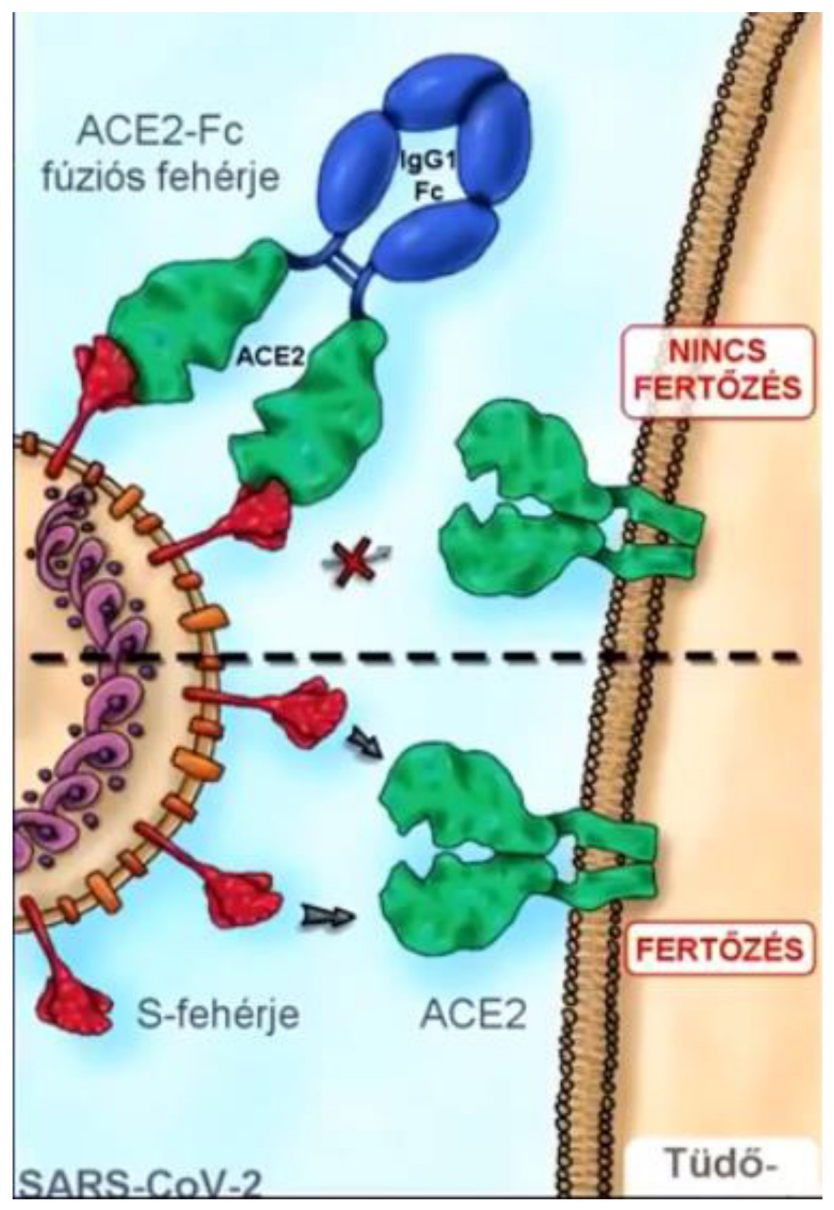

4. ábra

Az ACE2-Fc fúziós fehérje megakadályozza, hogy a gazdasej ACE2 receptorai felismerjék a SARS-CoV-2 koronavírust, és ezáltal az nem képes fertőzést indukálni (forrás: Marx Anita és Kacskovics Imre - ELTE TTK Immunológiai Tanszék)

amelyen keresztül az a sejtekbe hatol. A vírus így az emberi sejtek receptorai helyett a fúziós fehérjéhez kötődik. A másik komponense az IgG stabilitásáért felelös ún. Fc-régió (4. ábra).

A fejlesztés alapötletét 2020. február elején, a járvány kirobbanásakor az ELTE kutatói vetették fel. A Richter Gedeon NyRt. munkatársai már sikeresen elóállították a hatóanyagot, és analitikai vizsgálatokkal igazolták, hogy nagyon erősen kötődik a koronavírus tüskefehérjéhez. Ez hasonló mértékü a monoklonális antitestekéhez, ami lehetővé teszi, hogy várhatóan azokhoz hasonló hatékonysággal képes semlegesíteni a vírust. Az mEa-val öszszehasonlítva egy fontos előnye az ACE2-Fc terápiának, hogy gyakorlatilag minden patogén vírusmutáns ellen véd, hiszen amennyiben a vírus úgy mutálódik, hogy nem képes a hatóanyaghoz erősen kapcsolódni, akkor a sejtek felszínén lévő ACE2 receptorhoz sem fog tudni kötődni, így ártalmatlanná válik. Az elmúlt hónapokban a Pécsi Tudományegyetem Szentágothai János Kutatóközpont kutatói igazolták, hogy az ACE2-Fc hatóanyag sejtkultúrában gátolja a SARS-CoV-2 fertőzőképességét, valamint állatkísérletekben is hatékonynak bizonyult. Az ELTE és az ImmunoGenes kutatói igazolták, hogy a gyógyszer hosszú ideig kimutatható a kísérleti állatok szervezetében, valamint az emberi hatékonyság előrejelzése érdekében további, immár humán relevanciájú állatkísérletek is elindultak. Az ipari partnerként együttmüködő Richter Gedeon NyRt. szakértőinek köszönhetően az indulástól kezdve a gyógyszeripari minőségbiztosítás szempontjainak és a forgalomba hozatal feltételeinek figyelembevételével folyik a fejlesztés. Hazai és külföldi szakértők bevonásával már zajlik annak a törzsanyagnak az előkészítése, ami hamarosan az Európai Gyógyszerügynökséghez (EMA) kerül benyújtásra.

\section{Akadémiai-gyógyszeripari közös fejlesztés}

A SARS-CoV-2 koronavírus ellen ható antivirális szerek egyik legfontosabb támadáspontja az RNS-függő RNS polimeráz (5. ábra). Ez a fehérje más RNS vírusokban is megtalálható, amelyek ellen korábban több specifikus gátlószert is kifejlesztettek. Ezek közé tartozik egy széles spektrumú antivirális gyógyszer, a favipiravir is (FurutaKomeno-Nakamura 2017), amelynek hazai gyártásához szükség volt a hatóanyag, illetve a gyógyszerkészítmény előállítására alkalmas gyártóeljárás kifejlesztésére.

A favipiravir COVID-19 fertőzés kezelésében való hatékonyságának és biztonságosságának igazolására pedig tudományos igényű klinikai vizsgálatok kellenek. Ennek érdekében indult meg a magyar favipiravir-fejlesztés, amelynek alapvetően három célja volt. Az első cél a független hazai gyártás biztosítása a magyar COVID-19 betegek számára, második célja a készítmény tudományos igényü klinikai vizsgálata, amelynek érdekében két klinikai vizsgálatot készítettünk elő. Az első egy multi-

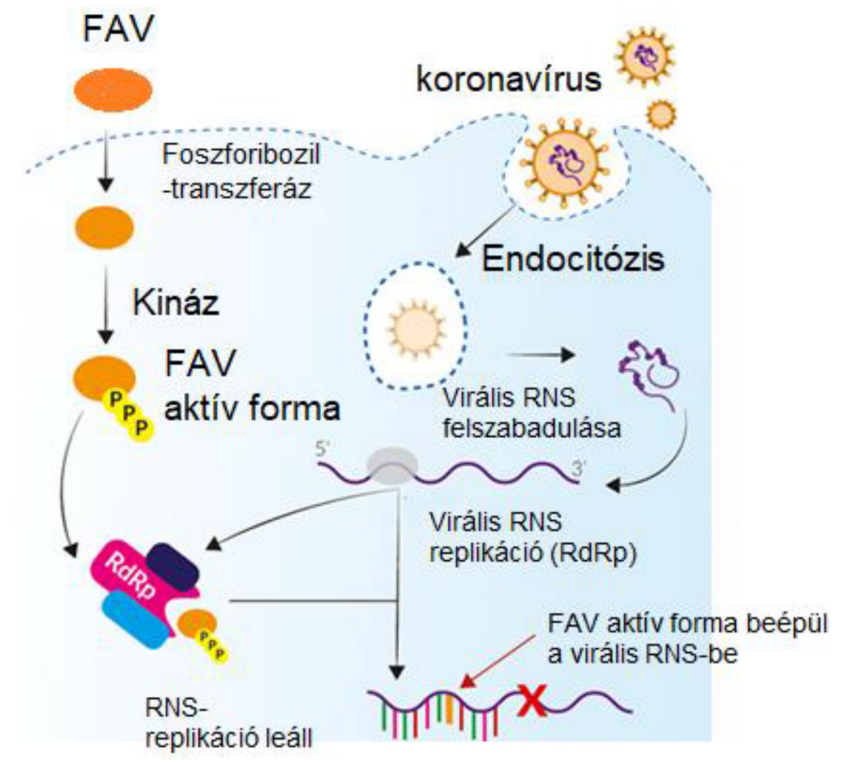

5. ábra $\mid$ A favipiravir (FAV) múködési mechanizmusa. A hatóanyagot a foszforibozil-transzferáz enzim viszi be a fertôzött gazdasejtbe, ahol előbb a foszforilált aktív formává alakul, majd az RNS-függő RNS polimeráz ( $R d R p)$ segítségével beépül a virális RNS-be, és ezzel leállítja a vírus szaporodását. (Az ábra az Invitrogen cég ábrájának adaptálásával készült, www.invitrogen.com.) 
centrumos, placebo kontrollált, adaptív Fázis 2/Fázis 3 vizsgálat a magyar favipiravir készítménnyel. A másik egy open label Fázis 3 referenciavizsgálat a japán Avigan készítménnyel. A projektek harmadik lehetséges célja, hogy amennyiben a favipiravir hatékonysága és biztonságossága a COVID-19 fertőzésben igazolódik, akkor a gyártás felfuttatásával a favipiravir lehetséges exportcikk is lehet Magyarország számára.

A magyar favipiravir fejlesztéssel kapcsolatos projektben az elsődleges cél egy klinikai vizsgálatra alkalmas gyógyszerkészítmény létrehozása volt. Az ehhez szükséges laboratóriumi eljárás kidolgozását a Természettudományi Kutatóközpont végezte. A méretnövelés az Első Indusztria Zrt.-nél történt. A félüzemi gyártóeljárás kidolgozása a Richter Gedeon Nyrt.-ben, míg a gyógyszerkészítmény fejlesztése és gyártása a Meditop Kft.ben valósult meg. A projekt sikeres megvalósításával rendelkezésre álló magyar favipiravir gyógyszerkészítmény, valamint a Japánból származó Avigan gyógyszerkészítmény klinikai vizsgálatát a Pécsi Tudományegyetem vezetésével klinikai vizsgálatok szervezésére és lebonyolítására létrejött HECRIN konzorcium végzi. A klinikai vizsgálóhelyek magukban foglalják a négy orvostudományi egyetem klinikai centrumait, valamint a Dél-pesti Centrumkórház Országos Hematológiai és Infektológiai Intézetet, illetve az Országos Korányi Immunológiai Intézetet. Amennyiben ezek a vizsgálatok sikeresen zárulnak, úgy a projektek nemcsak a magyar betegek gyógyulásához járulnak hozzá, hanem a nemzetközi közösség COVID-19 ellenes erőfeszítéseihez is.

\section{Konklúzió}

A bemutatott példák szemléletesen bizonyítják, hogy az akadémiai és ipari szereplők együttmúködésének köszönhetően gyors választ tudtunk adni a COVID-19 pandémia okozta kihívásokra. Bár az egyes programok időskálája lényegesen különböző, a korai kutatási programok középtávon, a fejlesztési programok pedig rövid távon, illetve akár azonnal hozzájárulhatnak a koronavírus elleni védekezéshez. Utóbbiak esetében a gyorsaság mellett lényeges szempont az ellátásbiztonság kérdése is, hiszen a hazai iparvállalatoknak köszönhetően a magyar állam nincs kiszolgáltatva a pandémia miatt rendkívül kitett nemzetközi piacnak. Ezáltal a magyar betegek ellátása prioritásként kezelhető, aminek kedvező egészségügyi, gazdasági és biztonsági aspektusai is nyilvánvalóak. A rendkívüli helyzet okozta összefogás tapasztalatai azt is megmutatják, hogy az állam részvételével megvalósuló akadémiai-ipari együttmúködések a korábbiaknál lényegesen hatékonyabban tudják szolgálni azokat a társadalmi igényeket, amelyek a népbetegségek elleni küzdelemhez és az egészségben eltöltött életévek fokozatos növeléséhez kapcsolódnak.

\section{Köszönetnyilvánítás}

Köszönettel tartozom prof. dr. Kacskovics Imrének és dr. Gál Péternek az általuk vezetett projektekre vonatkozó információkért.

\section{Irodalomjegyzék}

Furuta, Y., Komeno, T., \& Nakamura, T. (2017) Favipiravir (T-705), a broad spectrum inhibitor of viral RNA polymerase. Proceedings of the Japan Academy. Series B, Physical and biological sciences, Vol. 93. No. 7. pp. 449-463. https://doi.org/10.2183/ pjab.93.027

Guy, R. K., DiPaola, R. S., Romanelli, F., \& Dutch, R. E. (2020) Rapid repurposing of drugs for COVID-19. Science (New York, N.Y.) Vol. 368. No. 6493. pp. 829-830.

Hoffmann, M., Kleine-Weber, H., Schroeder, S., Krüger, N., Herrler, T., Erichsen, S., Schiergens T. S., Herrler, G., Wu, N.-H., Nitsche, A., \& Müller, M. A. (2020) SARS-CoV-2 Cell Entry Depends on ACE2 and TMPRSS2 and Is Blocked by a Clinically Proven Protease Inhibitor. Cell, Vol. 181. No. 2. pp. 271-280.

Khanna, I. (2012) Drug discovery in pharmaceutical industry: productivity challenges and trends. Drug Discov Today, Vol. 17. No. 1920. pp. 1088-1102.

Kneller, R. (2010) The importance of new companies for drug discovery: origins of a decade of new drugs. Nat Rev Drug Discov. Vol. 9. No. 11. pp. 867-882.

Konrat, R., Papp, H., Szijártó, V., Gesell, T., Nagy, G., Madai, M., ... Nagy, E. (2020) The Anti-histamine Azelastine, Identified by Computational Drug Repurposing, Inhibits SARS-CoV-2 Infection in Reconstituted Human Nasal Tissue In Vitro. bioRxiv. DOI: https://doi.org/10.1101/2020.09.15.296228. (This article is a preprint and has not been certified by peer review)

Lei, C., Qian, K., Li, T., Zhang, S., Fu, W., Ding, M., \& Hu, S. (2020) Neutralization of SARS-CoV-2 spike pseudotyped virus by recombinant ACE2-Ig. Nature Communications, 11, Article no. 2070. https://doi.org/10.1038/s41467-020-16048-4

Lincker, H., Ziogas, C., Carr, M., Porta, N., Eichler, H.-G. (2014) Regulatory watch: where do new medicines originate from in the EU? Nat Rev Drug Discov. Vol. 13. No. 2. pp. 92-93.

Mullard, A. (2018) FDA drug approvals. Nat Rev Drug Discov. Vol. 18. No. 2. 85-89.

Patridge, E. V., Gareiss, P. C., Kinch, M. S., Hoyer, D. W. (2015) An analysis of original research contributions toward FDA-approved drugs. Drug Discov Today, Vol. 20. No. 10. pp. 1182-1187.

Schuhmacher, A., Gassmann, O., Hinder, M. (2016) Changing R\&D models in research-based pharmaceutical companies. J Transl Med. Vol. 14. Article no. 105. 